Green, J., Pavlish, J., Leete, J., and Alexander, Jr., E. (2003) Quarrying Impacts on Groundwater Flow Paths. Sinkholes and the Engineering and Environmental Impacts of Karst (2003): pp. 216-222. Proceedings of the Ninth Multidisciplinary Conference on Sinkholes and the Engineering and Environmental Impacts of Karst, held in Huntsville, Alabama, September 6-10, 2003. Sponsored by the Geo-Institute of ASCE: the National Ground Water Association; P.E. LaMoreaux and Associates, Inc.

\title{
QUARRYING IMPACTS ON GROUNDWATER FLOW PATHS
}

\author{
Jeffrey A. Green ${ }^{1}$, Jeremy A. Pavlish ${ }^{2}$, Jeanette H. Leete ${ }^{3}$, E. Calvin Alexander, Jr. ${ }^{4}$
}

Proceedings of the Ninth Multidisciplinary Conference on Sinkholes and the Engineering and Environmental Impacts of Karst, held in Huntsville, Alabama, September 6-10, 2003. Sponsored by the Geo-Institute of ASCE: the National Ground Water Association; P.E. LaMoreaux and Associates.

ABSTRACT: Quarrying in limestone aquifers can interfere with groundwater flow paths. Quarries can pirate karst conduit flow by physically breaking into the conduits and changing the groundwater discharge points. Another mechanism of groundwater flow interference occurs as quarry dewatering lowers the water table changing groundwater flow directions. Dye tracing is an effective tool to evaluate and quantify these impacts. In Minnesota, tracing investigations have been conducted at two quarries.

The Big Spring quarry near Harmony, Minnesota is in the Ordovician Galena Formation. The quarry is 500 meters from Big Spring, the headwater spring of Camp Creek, a Minnesota designated trout stream. Although the quarry is nominally above the water table, beginning about forty years ago, the quarry intercepted conduits carrying groundwater to the spring. Groundwater that formerly discharged from Big Spring now rises in the quarry then flows overland joining Camp Creek 100 meters downstream of Big Spring. About 90 percent of the mapped groundwater basin of Big Spring is now routed through the quarry.

The Osmundson quarry is in the Devonian Lithograph City Formation at LeRoy, Minnesota. This sub-water table quarry requires seasonal dewatering at 1,000-3,000 liters/minute. When the quarry is being dewatered, Sweets Spring, approximately 300 meters to the southeast, stops flowing. Dye tracing has verified that the quarry pirates the flow to the spring.

Both of these cases demonstrate the utility of using dye traces to determine the impact of limestone quarrying on groundwater flow paths. This information can be used to evaluate

1 Regional Groundwater Specialist, Minnesota Department of Natural Resources, Division of Waters, 2300 Silver Creek Road NE, Rochester, MN 55906; jeff.green@dnr.state.mn.us

2 Quarry Study Hydrologist, Minnesota Department of Natural Resources, Division of Waters, 2300 Silver Creek Road NE, Rochester, MN 55906; jeremy.pavlish@dnr.state.mn.us

${ }^{3}$ Hydrogeologist Supervisor, Minnesota Department of Natural Resources, Division of Waters, 500 Lafayette Road, St. Paul, MN 55155-4032; jeanette.leete@dnr.state.mn.us

4 Professor, Geology \& Geophysics Department, University of Minnesota, 108 Pillsbury Hall, 310 Pillsbury Drive SE, Minneapolis, MN 55455; alexa001@umn.edu 
proposed quarry sites for their potential alterations of groundwater flow paths.

\section{INTRODUCTION}

Quarrying of limestone and dolomite is a common activity in karst areas. The rock products are used for a variety of uses including road aggregate, cement production, and industrial processing. Quarries alter the shape of the landscape and can impact water quality and quantity in a number of ways. The removal of overlying material can increase the vulnerability of the aquifer to pollution, conduits can be physically disrupted leading to reduced flow in springs, and de-watering of sub-water table quarries lowers the water table and can impact neighboring wells and springs (Hobbs \& Gunn, 1998). In 2000, quarries in Minnesota produced about 10 million metric tons of limestone and dolomite with an approximate value of $\$ 50,000,000$ (Minnesota Department of Natural Resources, 2001).

Minnesota Department of Natural Resources, Division of Waters hydrologists have been investigating quarrying impacts on groundwater systems. Past work includes investigations into the impact of seasonal dewatering on lake levels (Beissel \& Ford, 1981). Recent work has focused on the impacts on wells and springs of quarry dewatering and conduit piracy.

Dye tracing can be an effective tool to investigate these impacts. Two Southeastern Minnesota quarries were investigated in areas with an abundance of sinkholes and springs. The locations of the quarries, Big Spring quarry in Fillmore County and the Osmundson-LeRoy quarry in Mower County are shown in Figure 1. This work is being done to document how these quarries have changed the local groundwater flow paths.

\section{METHODS}

Tracer dyes were used to determine the groundwater flow paths. The dyes used were eosine (CAS 17372-87-1), Rhodamine WT (CAS 37299-86-8), and fluorescein (CAS 518-47-8). Three dyes were used to allow us to trace from up to three different sinkholes at the same time in order to expedite basin mapping. The traces were carried out with $200-800$ grams of dye flushed with approximately 9,000 liters of water from a tanker truck; sinkholes were the injection point for all of the dye traces. Passive charcoal detectors and direct water samples were used for sampling. The samples were analyzed with a Shimadzu RF5000 scanning spectrofluorophotometer at the University of Minnesota Department of Geology \& Geophysics using standard dye tracing techniques (see for example, Aley, 1999) and PeakFit for spectral decomposition.

\section{SITE INVESTIGATIONS Osmundson-LeRoy Quarry}

This quarry is in the Lithograph City Formation of the Devonian Cedar Valley Group. It is relatively flat-lying limestone with some interbedded dolostone and shale (Mossler, 1995). The quarry area in 2001 was approximately 30 ha; 17 ha require seasonal dewatering, the remaining area is above the water table. 


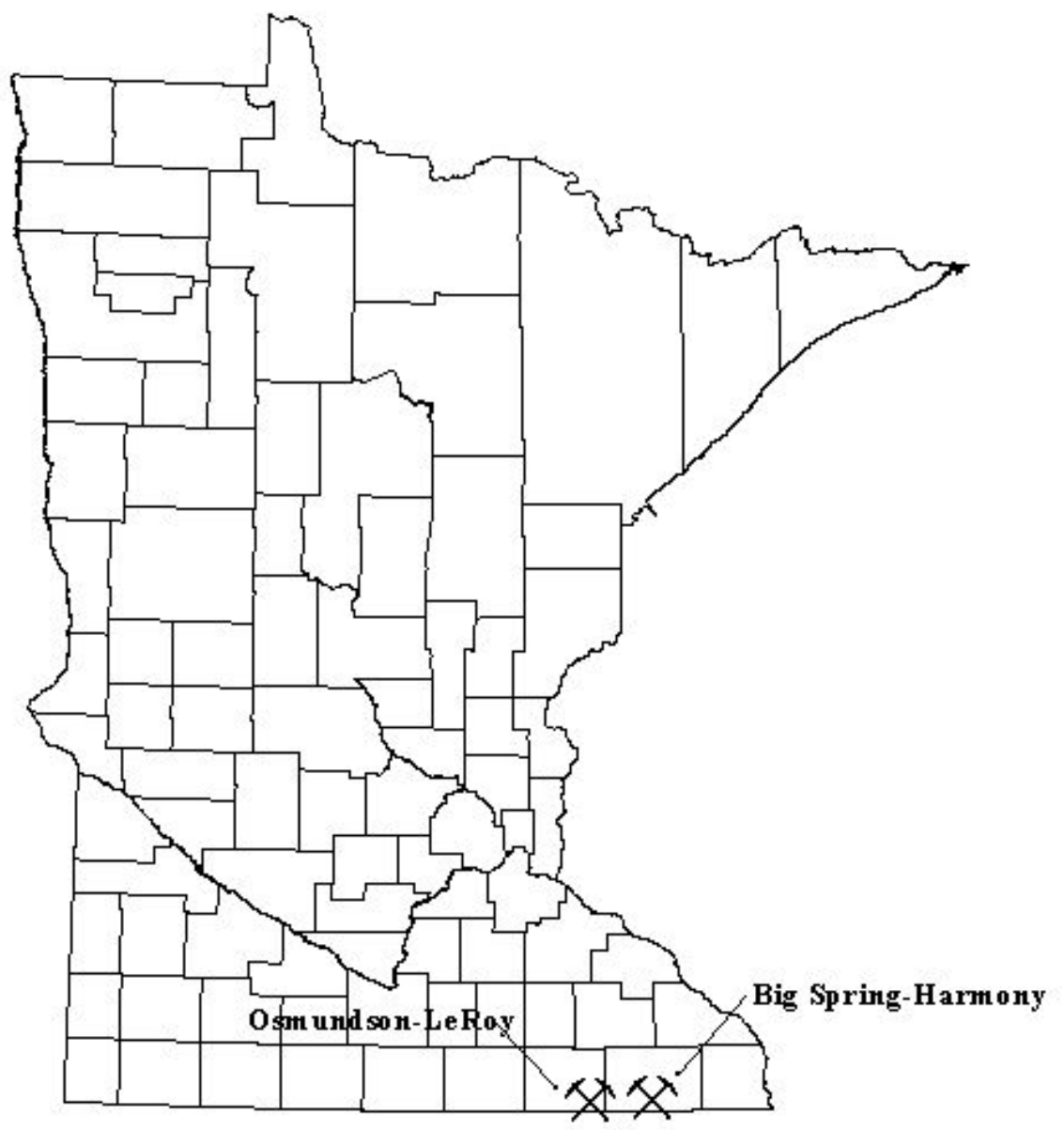

FI G. 1. Location of study sites.

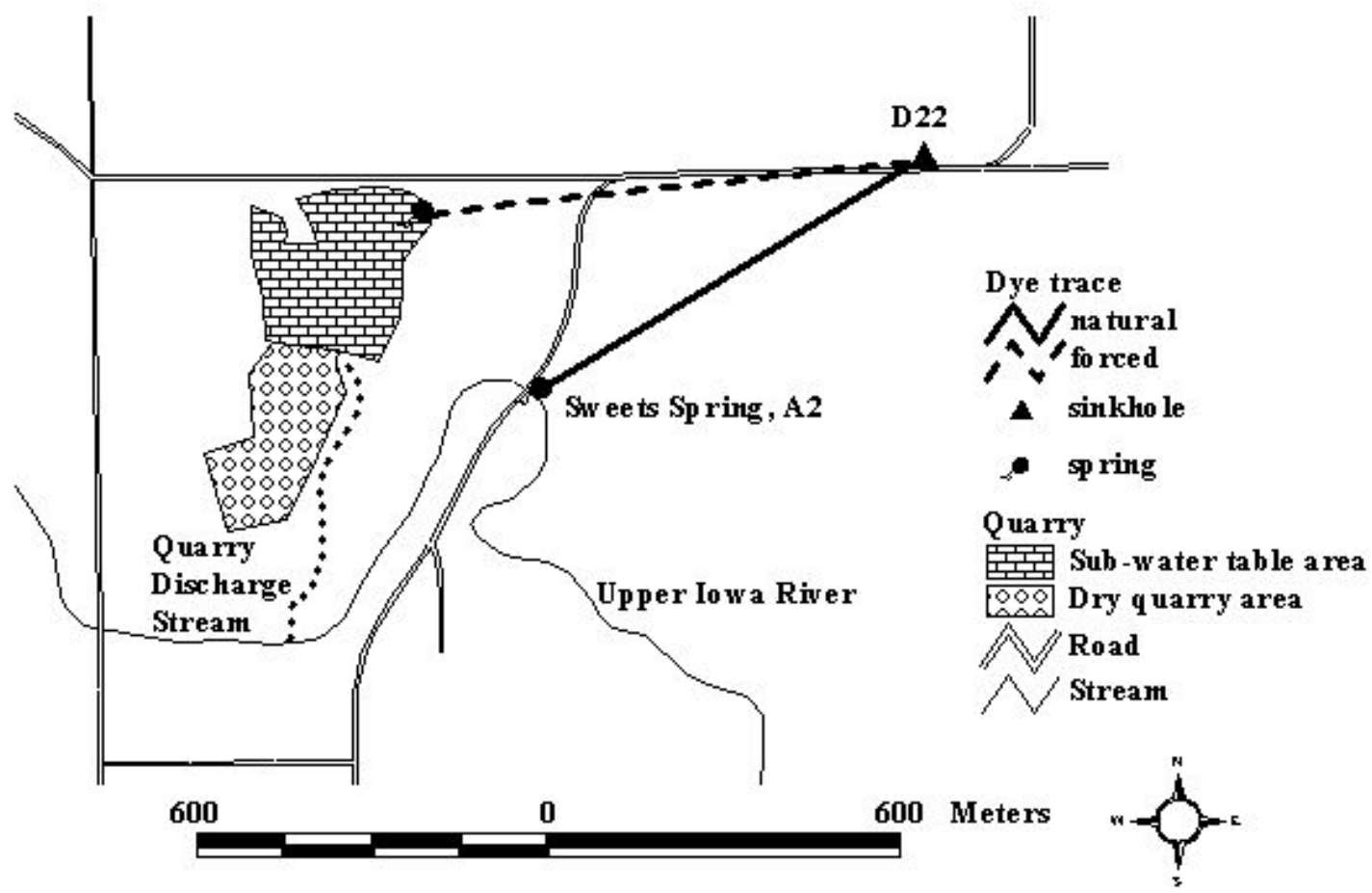

FIG. 2. Na tural and fo reed gradient dye tracing at the Osm und son quarry, Le Roy, MN. 
Dewatering is done at a rate of 1,000-3,000 liters/minute and the water is then discharged to the Upper Iowa River which is approximately 500 meters south of the quarry sump. The quarry operators do not dewater year-round nor do they dewater every year. They lower the water table for the summer work season and then stockpile enough rock in the dry area of the quarry for the following year. The quarry is then allowed to fill back up with groundwater.

Sweets Spring (A2), a perennial spring feeding the Upper Iowa River, is approximately 300 meters southeast of the quarry. The spring stops flowing when the quarry is dewatered. Two dye traces were conducted from a sinkhole, D022, which is 780 meters northeast of Sweets Spring and 850 meters northeast of the quarry. The results of these two traces are shown in Figure 2. The first trace (dashed line in Figure 2) was done while the quarry was being dewatered and the spring was dry; the second (solid line in Figure 2) was conducted when no dewatering was occurring and the spring was flowing.

Dewatering at the quarry pirates the groundwater flow from Sweets Spring. The second trace, performed under a natural gradient, shows that the normal groundwater flow path in the immediate vicinity of the spring is restored when the quarry is not being dewatered. The rate of groundwater movement during these traces was 400 to 500 meters/day. This is the first documented case in Minnesota of a quarry totally capturing the flow of a karst spring.

\section{Big Spring Quarry}

The Big Spring quarry is in the flat-lying Stewartville and Prosser Members of the Ordovician Galena Group. The Prosser is fine-grained, thin-bedded limestone with minor shale partings while the Stewartville is fine-grained dolomitic limestone and dolostone (Mossler, 1995). The quarry area as of 2002 was approximately 17 ha. In the early 1960's, quarrying operations disrupted the conduits carrying flow to Big Spring (A24), the headwaters of a trout stream, Camp Creek, which lies 500 meters north of the quarry. The owners of the spring have stated that when this disruption occurred, the flow from the spring decreased. At that time, water started rising in the quarry at several different points; some flows overland to Camp Creek while the rest sinks back into the quarry and resurges in Big Spring (A24). The ratio of overland flow versus resurging flow varies depending upon spring stage and runoff events.

Dye traces were conducted in the area as part of the Department of Natural Resources County Geologic Atlas mapping effort (Alexander et al., 1995). This work was an attempt to map out the basins feeding some of the large springs in the county. Boundaries between the Big Spring basin and other basins were partially established during this project. As part of our current research on quarrying impacts to groundwater systems, we have been using dye tracing to refine the existing basin boundary map and determine how much of the basin area is being routed through the quarry.

Figure 3 shows the geologic atlas dye traces and the dye traces done as part of our current research. The quarry has had a profound impact on the local groundwater flow system. Based on the 1995 Springshed map and the additional tracing work done as part of this project, roughly 90 percent of the flow in the Big Spring basin is now being routed through the quarry. 


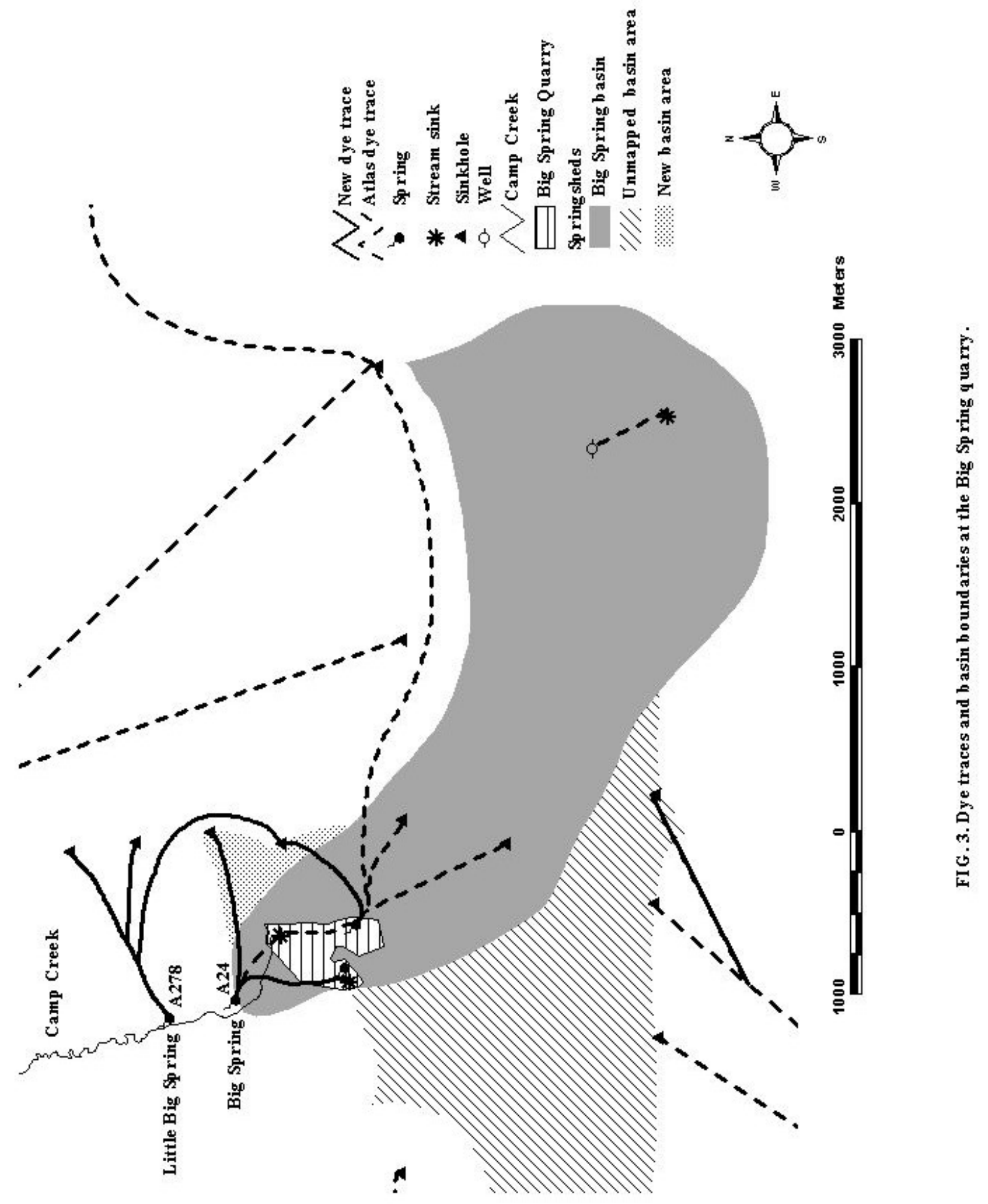





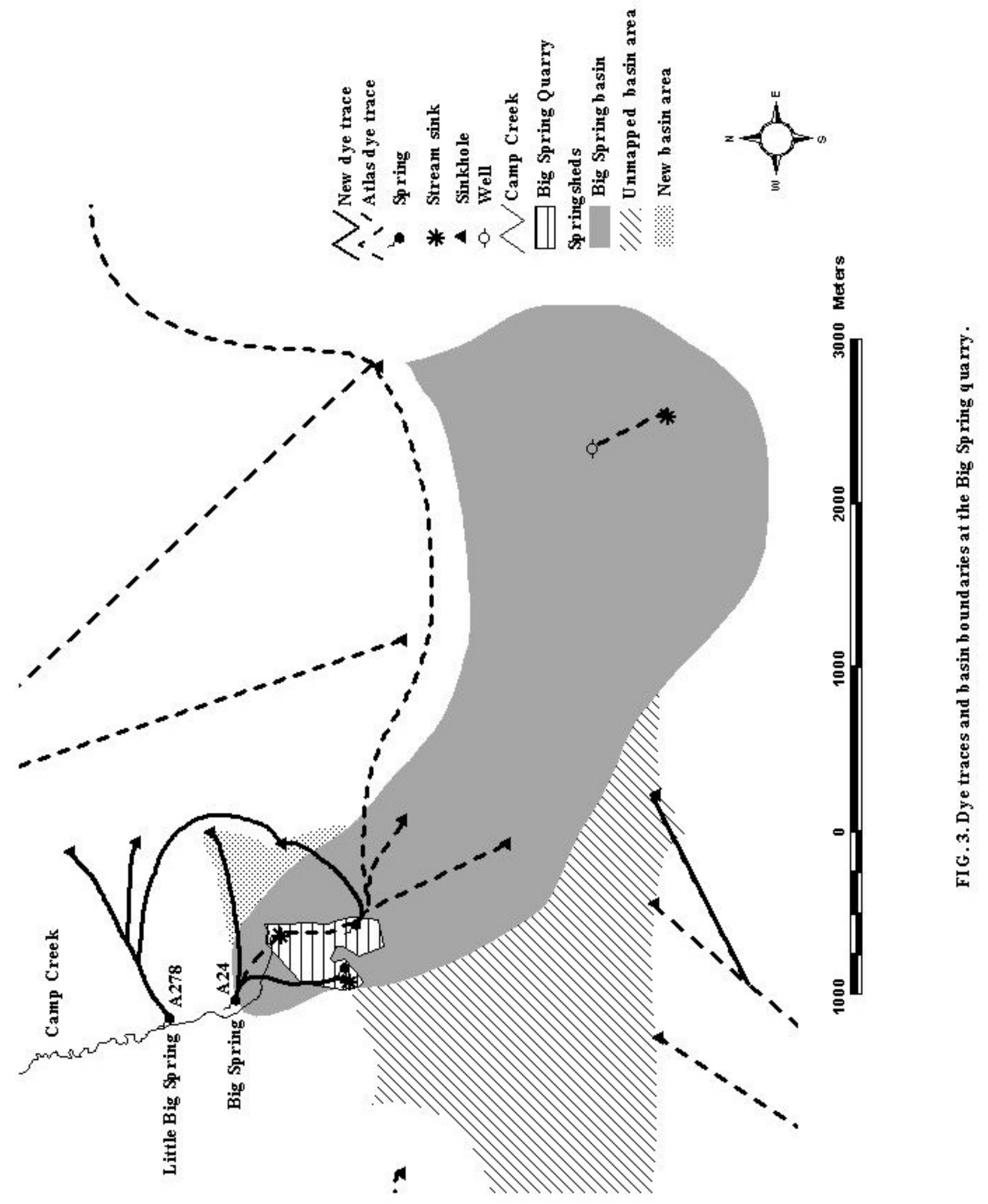




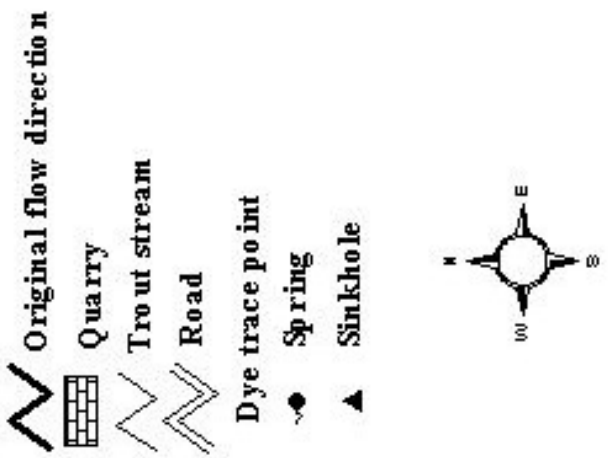

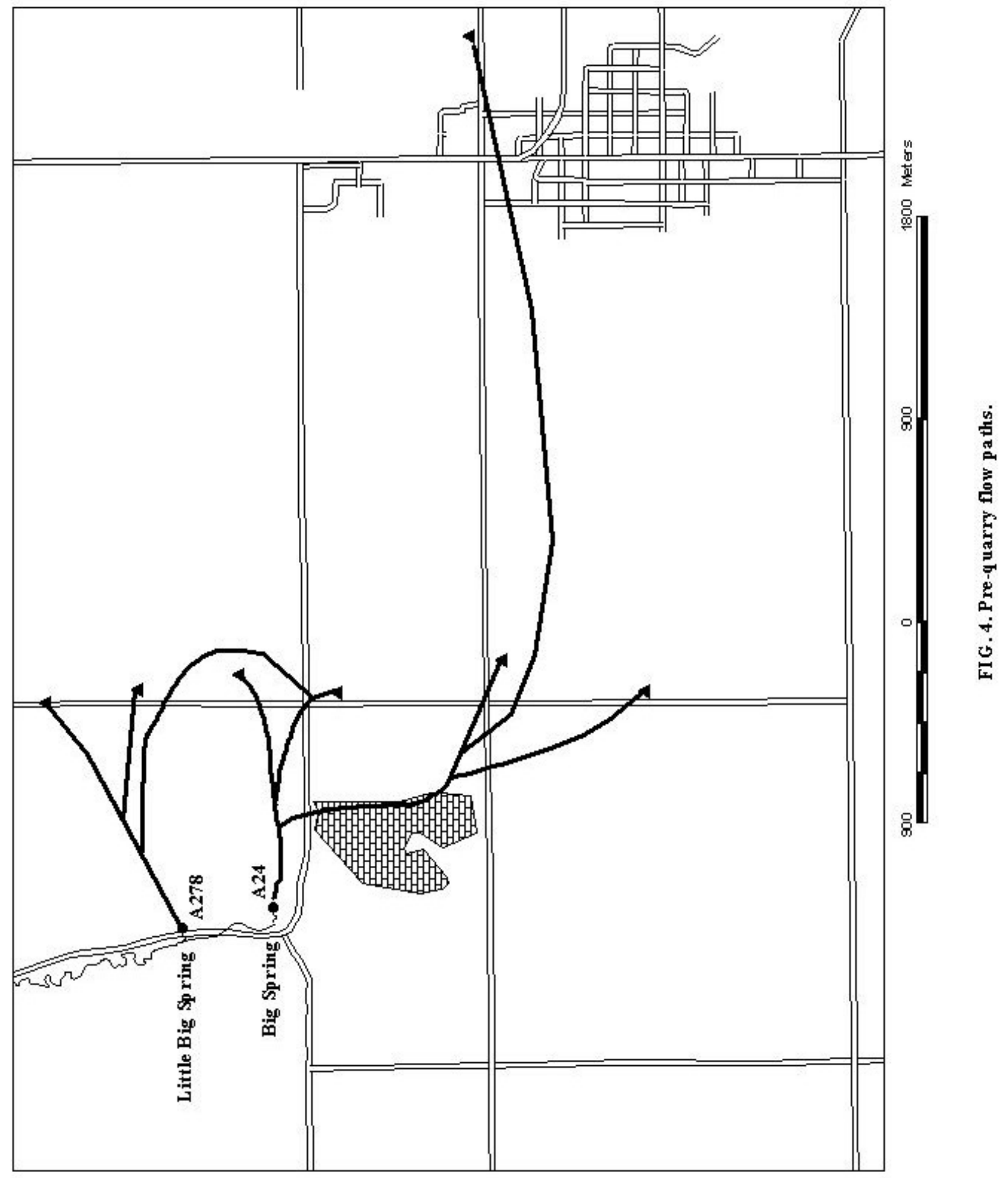


This exposes the conduit water to thermal impacts and makes it more vulnerable to pollution from quarrying activities. The dye trace from sinkhole D6015 demonstrates that the quarry is also pirating flow from Little Big Spring (A278). The rate of groundwater movement during these traces was 500 to 1,000 meters/day. Figure 4 is a diagrammatic reconstruction of the groundwater flow paths prior to the conduits being penetrated. The flow lines converged on Big Spring and the water discharged directly into the trout stream.

\section{SUMMARY}

By using dye tracing, we were able to document and quantify the scope of spring piracy at the Big Spring quarry. Based on available information, roughly 90 percent of the basin is now being routed through the quarry. Without any dewatering occurring, this quarry has altered groundwater flow paths. At the Osmundson-LeRoy quarry, we documented the first case in Minnesota of a quarry totally dewatering a spring. Both of these cases demonstrate the utility of using tracer dyes to determine the impacts of limestone quarrying on groundwater flow paths in karst.

\section{ACKNOWLEDGEMENTS}

Funding for this research has been provided by the Legislative Commission on Minnesota Resources Environment and Natural Resources Trust Fund and by the Minnesota Department of Natural Resources-Division of Waters. The City of Harmony Fire Department and the City of Leroy Fire Department willingly provided the water and tanker trucks necessary for running the dye traces.

\section{REFERENCES}

Alexander, E. C., Jr., Green, J. A., Alexander, S. C., and Spong, R. C. (1995). “Springsheds.” Geologic Atlas Fillmore County, Minnesota. County Atlas Series C-8, Part B, Plate 9. Mn. Dept. of Natural Resources, St. Paul, Minnesota.

Aley, T. (1999). Groundwater Tracing Handbook. Ozark Underground Laboratory, Protem, Missouri, 25-32.

Beissel, D. R., and Ford, D. R. (1981). "Hydrologic Effects of Quarry Dewatering on Dean Lake, Scott County, Minnesota - A Case Study.” Int. Symp on Urban Hydrology, Hydraulics, and Sediment Control, Lexington, Kentucky, 425-429.

Hobbs, S. L., and Gunn, J. (1998). “The Hydrogeological Effect of Quarrying Karstified Limestone: Options for Prediction and Mitigation.” Quarterly J. of Engineering Geology, GSA, 31, 147-157.

Minnesota Department of Natural Resources, (2001). The Mineral Industry of Minnesota, 2001, Minn. Dept. of Natural Resources, Division of Lands and Minerals, St. Paul, Minnesota.

Mossler, J. H. (1995). “Bedrock Geology.” Geologic Atlas Fillmore County, Minnesota. County Atlas Series C-8, Part A, Plate2. Minn. Geological Survey, St. Paul, Minnesota.

Mossler, J. H. (1998). “Bedrock Geology” Geologic Atlas Mower County, Minnesota. County Atlas Series C-11, Part A, Plate2. Minn. Geological Survey, St. Paul, Minnesota. 
Keywords: dye tracing, limestone, quarrying, groundwater, springs, karst, conduit piracy, Minnesota 